Journal of International Business and Economy (2020) 21(2): 116-130 (15 pages)

JBE

Journal of International Business
and Economy

Gowsia Bashir and Mubashir Majid Baba

\title{
FRANCHISING AND ECONOMIC GROWTH: A MACRO PERSPECTIVE
}

\begin{abstract}
Much of the research conducted in India in the area of entrepreneurship considers the relation between entrepreneurship and economic performance. However, the latest business strategy that has shown tremendous development in business arena has been ignored altogether. The present paper provides a theoretical framework of the relationship between franchising business and national economic performance. The main aim of this paper is to present the capabilities of applying the concept of franchising in the development of entrepreneurship in SME sector so as to trigger-economic performance. This article argues that there is a need to treat franchising not just a mere business expansion option but a powerful SME development strategy that has a capability to change the economic fate of the country like entrepreneurship does. The first part deals with some aspects of the recent economics literature on the relationship between entrepreneurship, small business, and economic growth. The second part a conceptual framework presents the links between franchising and economic growth at different levels of aggregation. In particular, it gives a summary of some research works across the world.
\end{abstract}

Key Words: Franchising, Entrepreneurship, Business Expansion Strategy, Economic growth, SME development

Gowsia Bashir

Department of Management Studies, University of Kashmir

MubashirMajid Baba

Department of Management Studies, University of Kashmir

Correspondence: Gowsia Bashir

E-mail:shahgousia321@gmail.com

Journal of International Business and Economy

Fall 2020 


\section{INTRODUCTION}

Entrepreneurs help in new business creation, which in turn helps in creating jobs, trigger competition, and possibly will even lead to higher productivity through technological changes. High levels of entrepreneurship will thus directly led to high levels of economic performance. However, the reality is something which is more complicated than this. Entrepreneurship and economic growth have shown a close and positive link together since the early works of Schumpeter (Schumpeter, 1911). A survey was conducted by researchers of Global Entrepreneurship Monitor (GEM, 2000) program - a research committee of a multi- country survey effort mainly involved in annual assessment of the national level of entrepreneurial activity in order to understand how different types of entrepreneurship affect development. The national level of entrepreneurial activity has got a significant association with consequent levels of economic growth (GEM, 2002). No country there has got high levels of entrepreneurship and low levels of economic growth (Reynolds et al., 2002). The GEM started by making a clear distinction between two broad types of entrepreneurs- "necessity entrepreneurs," which are having no better option left to them other than becoming an entrepreneur and "opportunity entrepreneurs", being an active choice in starting a new enterprise based on the perception that an unexploited or underexploited business opportunity exists. As per the survey conducted by the GEM researchers in 11 different countries, it was found that the development of these two types of entrepreneurship (necessity entrepreneurship and opportunity entrepreneurship) and effects on the economic growth vary greatly. It was found that there is a positive and significant effect shown by opportunity entrepreneurship on economic growth while as necessity entrepreneurship hasn't any effect on economic performance (Acs and Varga, 2005). Necessity entrepreneurs being pushed into entrepreneurship (self-employment) either due to absence or unsatisfactory options for work may not lead to economic development. Entrepreneurship has been found to be the driving force of economic growth as entrepreneurs play a fundamental role in most production, distribution, and growth theories. The process of entrepreneurial discovery involves finding new combinations of factors of production that becomes the engine that drives economic development (Schumpeter, 1911).

Innovative entrepreneurship leads to business cycles making the firms to generate newer ideas and implement them into new products, processes or a service which in turn leads to the dynamic growth of the national economy, increase in employment 
opportunities and also helping the innovative enterprises to generate pure profit (Dejardin, 2000; Jääskeläinen, 2000; Thurik and Wennekers, 2001; Barreto, 1989).Growth in advanced industrial economies is driven by technological change and knowledge accumulation as a result of the R\&D efforts of firms (Peretto, 1999). Ample empirical evidence studying the link between entrepreneurship and economic growth has been provided by several researchers by using different measures of entrepreneurial activity in terms of the relative share of economic activity accounted for by small firms, selfemployment, the number of market participants (leading to intensity of competition) or firm start-ups as an indicator of entrepreneurial activities (Carree and Thurik, 2002; OECD, 1998). The analysis of GEM along with the recent studies on OECD countries provide important statistical evidence regarding entrepreneurial activity and economic growth (Kantis et al., 2002). The effect of market competition measured in terms of increase in the number of competitors (as a possible measure of entrepreneurship) has shown a positive impact one the development of companies' productivity performance i.e., total factor productivity growth (Nickell, 1996; Nickell et al., 1997). Invention and entrepreneurship are at the heart of national advantage (Porter, 1990). Acs and Audretsch (1993) and Carlsson (1992) provide evidence concerning manufacturing industries in countries in varying stages of economic development.

Various Conceptual models that provide a framework to link entrepreneurship to economic growth have been established by various researchers. One of the related framework models was proposed by Wennekers and Thurik (1999).

Figure 1: The Wennekers and Thurik Model

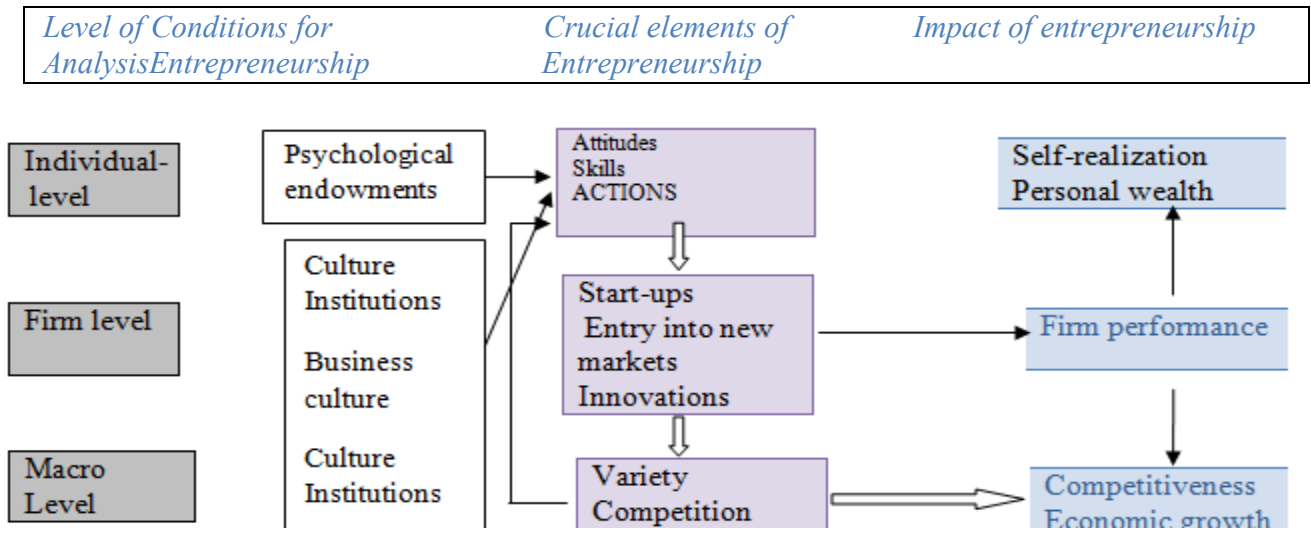

Source: Carree and Thurik (2002) 
The model distinct three levels of analysis-individual, firm, and macro level. The entrepreneurial activity begins at the individual level induced by one's attitudes or motives, skills, and psychological endowments getting influenced by cultural and institutional factors, the business environment, and macroeconomic conditions. This activity is confined to individual goals and wealth. Realization is achieved at the firm level, while as at the macro level of industries and national economies, the sum of entrepreneurial activities constitutes a variety of new ideas, initiatives, and competing experiments. This results in the change in the market in terms of selecting viable firms, replacement of obsolete firms and hence leads to the expansion and transformation of the productive potential of the national economy by inducing higher productivity.

\section{Methodology}

A systematic review process was adopted to carry out the literature review on franchising and economic growth. The literature search and review has been conducted by the researchers during February-April, 2020 and was further updated in July -August, 2020. Various scholarly articles were identified using multiple databases that include Emerald Insights, Elsevier, Sage, Ebsco, Pro-Quest Education Journals etc. Other than these databases, Sci-hub, LibGen, Google Scholar, Research gate etc. have been used to download the papers. With the research focus on the link between Entrepreneurship and Economic Growth, the keyword combination of "entrepreneurship" and "economic growth" was used to result in 98 articles found. Other than these keywords, databases were also searched by key words like franchising. There were such restrictions as peerreview, empirical study, and English publication. The studies whose abstracts provided vague descriptions of the research frameworks and measurements were reviewed in-depth for inclusion or otherwise.

\section{Franchising as a concept of entrepreneurship development in the SME sector}

Franchising is a mutual cooperation or legal contract between two entities in which one party the franchisor transfers the recipe for a particular business activity to another party the franchisee in exchange for an appropriate fee. The relationships between those entities lead to the creation of a franchise network (Chmielarski, 2002). The Majority of these entities are micro, small, and medium-sized enterprises (SMEs) that operate as franchisees, 
who take the franchising concept as an opportunity to obtain support towards their entrepreneurial activities. Entrepreneurship development in the SME sector is strongly associated with the release of private initiative and intellectual activity which focuses on wealth generation due to a combination of different manufacturing factors. As a result, implementation of newer ideas and innovation takes place (Borowiecki andSiuta-Tokarska, 2008)which has got positive economic and social impacts due to an increase in the number of active micro, small and medium-sized enterprises (Lchiewicz, 2003; Piasecki, 2001). However, entrepreneurial activities in the SME sector are restricted by certain development barriers both internal as well as external (Matejun 2007a; Matejun, 2007b) like the deficiency of creativity, lack of competencies, or limitations in terms of the motivation of resources (Safin, 2008). This makes the entrepreneurs to think out of the box and focus on the opportunities resulting from the application of various forms of supporting the private initiative, resourcefulness, etc. One of such concepts is franchising, which operates on the basis of a legal written contract signed between two legally, financially, and fiscally separate and independent enterprises. It is a very interesting concept of developing entrepreneurship in the SME sector which includes several but essential benefits like the proven market concept, a well-established brand name as well as the technical and organizational support provided by the franchisor (Grzelak and Matejun, 2013).

Franchisors, the real founders of business format systems meet all the requirements of entrepreneurship (Low and MacMillan, 1988). They create new ventures (Gartner, 1985), identify new opportunities (Stevenson et al., 1989), and carry out new combinations (Schumpeter 1934). Franchising involves introducing new products and services, leads to innovative marketing thus outruns the competition and results in the faster growth of the business (Aldrich and Auster, 1986; Gartner, 1985). Franchisors typically start by operating a single outlet, or chain, and then by means of licensing disperse their brands in different geographical locations (Kaufmann and Dant, 1996). Creating a franchise network for business signifies the opportunistic behavior of franchisors- one of the main characteristics of entrepreneurship (Hoy and Shane, 1998). As concluded by Stan worth et al. (2003), expansion of businesses by franchising concept adjudged from a financial, human resource, and ownership perspective by business owners seems to be very innovative. In most of the countries, franchising is treated as well adopted and most popular strategy and has developed as an organizational form for the last four decades (Grewalet al., 2011) strategically helping them to compete (Gillis et al., 2011) to the 
industries that involve highly decentralized operations at a chain of multiple sites (Michael, 2000). It has happened to be a well-accepted and fast-growing method of doing business approved worldwide (Combs et al., 2010; DiPietro et al., 2007; Shane and Foo, 1999).It is considered as a specific form of entrepreneurial cooperation. Due to competitive business environments, the need for entrepreneurial activities has increased in franchise systems helping the firms to improve their efficiency (Shane and Venkataraman, 2000). In service industries franchising helps the entrepreneurs to gain first-mover advantage by making them to accumulate resources and create large chains rapidly (Bygrave, 1997; Michael, 2003).Franchisors identify an opportunity, accordingly create and develop the business and are thus widely accepted as entrepreneurs (Rosa, 2005; Falbe et al., 1999; Ketchen et al., 2011). Most of the studies have viewed franchising as an entrepreneurial effort (Falbe et al., 1998). Although franchisee's activities may be to some extent restricted by the franchisors' rules and regulations, but they are also involved in developing new offerings, modifications of already existing ones and finding the solution to their franchise outlet problems whenever and wherever required (Kaufmann and Eroglu, 1999). Franchisees also identify and focus on the opportunities and take the business risk to start their ventures (Ketchenet al., 2011). Franchisees not only innovate in areas such as local marketing and new product development but also strengthen the system's competitive positioning in the marketplace(Baucus et al. 1996). When compared with the independent businesses success rates of franchisees makes franchise owners as entrepreneurs (Welsh et al. 2011).While studying the franchisor-franchisee relationships, most of the studies provide empirical evidence regarding the selection of franchisees by the franchisors and signify that franchisees are selected on the basis of suitable traits and attitudes helping them in managing franchise systems(Saraogi, 2009). Franchising acts as a well-accepted business development model and has proved to be the most effective and successful strategy helping the entrepreneurs in business diversification and expansion in unfamiliar markets without involving extra capital. Both franchisors and franchisees possess all the entrepreneurship traits when measured at the entrepreneurship trait matrix, and are usually the real entrepreneurs which enter into the franchising business in order to get the extra benefits offered by it.

\section{Franching and economic development}

It is important to know that franchising is not just an industry but a business expansion strategy in order to deliver a product or service to customers beyond the host markets. 
Developing a business is not so easy. What is more difficult is to build a business in the retail sector. There are several factors including marketing expenses, real estate, labor costs, and fast- changing consumer habits that add to the risk and complexity of the business sector. The greater challenge that the entrepreneurs are facing is to replicate the success of a retail concept in the new locations. In order to move to new places, the business needs to learn how to operate in countries with different environments, customer habits, labor laws, and different legal and tax codes. The most exciting experience was how the use of business format franchises helps the owners of the brand by reducing the risk because the franchisor while entering into a franchise contract transfers the specific knowledge about the business management to the franchisee and increasing the chances of successful ventures. The franchisees bring significantly important local knowledge and experience to the relationship that accelerates the learning curve for the franchisor. The vital information regarding the local market helps the franchisors to respond to the rapidly changing customer demands thus making the more relevant products and services. Franchising provides access to international markets and up-to-date technology and innovative products.

Franchised businesses are considered as one of the essential segments of the larger small business population. The economic impact of franchising can be seen by means of an increase in output, job creation, increase in the tax base, the balance of payments, entrepreneurship development, etc. (Dwivedy, 2002).The economic impact of franchising increases by an increase in direct sales and its multiplier effects. Franchising has got a significant impact on employment which can be calculated by increase in the number of outlets and the number of employees working in each unit. Franchising stimulates the local demand for a variety of products and services by providing employment and increasing the income of the employees which in turn magnifies the economic impact of host countries due to the availability of supplies and cost. It has been estimated that every franchise outlet on average maintains thirty-three jobs (13 direct and 20 indirect) by means of economic exchanges (Saunders, 2002). Another study has revealed that every $\$ 5000$ spend by a franchisor leads to the creation of one job (Siggel, Maisonneuve, and Fortin, 2003). In 2004, 7.76 million and 1.37 million jobs were created by franchised businesses both in business format and product distribution franchises respectively, which totals to 9.1 million jobs, or 6.2 percent of the total nonfarm, private sector employment, and nearly 18 million Americans are impacted by means of franchising business model with an overall output of $\$ 2.1$ trillion amounting to 9.0 percent of private, non-farm output 
including the indirect employment as well. As per the study conducted by the National Economic Consulting Practice of Pricewaterhouse Coopers in 2007 which was sponsored by the International Franchise Association Educational Foundation, there are more than 732,842 franchised outlets operating in US alone employing more than 18 million people providing nearly 14\% of US private-sector employment and in China, five million (Dant et al., 2011).This generates $\$ 1.53$ trillion in economic activity or nearly $10 \%$ of the privatesector economic output. In the USA, which is considered as the home of franchising (As per International Franchise Association, 2016) enterprises which are using this business model increased the number of jobs by 3.5\% (of which 278,000 are direct, in the economy as a whole - 7.6 million); over the last five years, the average increase in this indicator was 2.6\% (total - 1 million employed), which is $20 \%$ more than other industries. In 2016, the number of outlets increased by $5.8 \%(120,384-760,000)$, income increased by $1.7 \%$ (USD 520 billion- up to USD 994 billion), and GDP - by 5.7\% (USD 405 million - 22 billion in plus).

Raising tax revenues has got a positive impact on the development of the physical and institutional infrastructure of the emerging markets. International franchising has played a most prominent role in increasing the tax base of the countries due to their involvement and their franchisee networks. Economic modernization and economic development are closely linked to each other. Economic modernization is one of the most significant outcomes of franchise networks. Because most of the franchisors usually the large companies when entering into the emerging markets invest heavily in local markets in supporting infrastructure, production facilities, and various business along the supply chain in order to maintain the company standards (Alon and Banai, 2000). Innovation the main by-product of entrepreneurship is created by means of franchising in developing countries. Franchising is directly involved in disseminating the newer technologies and bringing up the new business models in the local markets, contributing to productivity and growth. It has been estimated that domestic franchisees contribute $15 \%$, while franchisors contribute 25\%of all innovations (Siggel, Maisonneuve, and Fortin, 2003).

Nowadays, the contribution to the main macroeconomic indicator is about 3\%.As per the economic forecast, the leading sector in the franchising business is the hotel sector with an increase of $6.6 \%$ in production that has shown steady growth in past periods both in developed and developing (International Franchise Association, 2016). As per International Franchise Association, there are round about 75 different industries that use this strategy of franchising. According to Romanian Franchise Association, there are more 
than 483 franchise networks operating in Romania in various business fields while in Europe, there are about 10000 franchise networks, 4000 in China, 1200 in Japan, and 1000 in Australia. In Latin America, in order to boost the economic growth, franchising has played a prominent role, while as in few countries like Brazil and Mexico its boom has undoubtedly happened where the number of franchises operating reached 2,703 and 1,499 brands, respectively in 2013 (Fadairo and Lanchimba, 2017).

Franchised businesses can be considered as engines of employment growth, like the larger small business population, especially in strong economic times. During the depth of the recession in 2007 and 2008, unlike all businesses which declined rapidly, franchised enterprises recovered very fast and outpaced all other businesses as a whole over the time period. Indeed, franchised small businesses provide new franchisee opportunities in both host countries and abroad thus lead to new employment and growth for franchisors. Tremendous growth opportunities are provided by the International markets to the domestic franchisors for growth and development. It is clearly understood that the franchise business model provides scalability and global growth to the firms, thus helps in creating high-paying jobs worldwide at the franchisor's headquarters. Expansion of business globally by means of franchise businesses can directly help the international balance of payments of the host countries as franchisees pay their royalties to franchisors and such royalty payments increase with a growing global economy. This helps the franchisors to pursue international opportunities, by providing resources domestically- readily available credit access and favorable business conditions - thus making the global expansions easy and in reality.

\section{DISCUSSIONS AND CONCLUSION}

The present study has endeavoured to review and evaluate the research from 1980 to 2017 on franchising and economic growth. Much of the research conducted in India in the area of entrepreneurship considers the relation between entrepreneurship and economic performance. However, the latest business strategy that has shown tremendous development in the business arena has been ignored altogether. There is a need to treat franchising not just as a mere business expansion option but a powerful SME development strategy that has the capability to change the economic fate of the country like entrepreneurship does. The present paper provides a theoretical framework of the relationship between franchising business and national economic performance. A 
systematic review process was adopted to carry out the literature review on franchising and economic growth. A database search was carried out, and 98 articles were retrieved. The study analyzed the franchise's contribution to the country's development. Due to franchise development, everything comes in a bundle; a developed economy attracts the foreign franchises to operate in the country, which translates into a change in the population due to a shift in culture. More and more jobs are created by franchise development creating a positive shift in society. Indeed, entrepreneurs who wish to expand their business usually face certain difficulties in terms of availability of resources whether it is finance, human resource thus making most of the entrepreneurs to confine to host markets only. But the franchise business model is responsible for providing key resources to entrepreneurs to open their own establishments, and it allows for these business owners to grow up very quickly.

The study deals with some aspects of the recent economics literature on the relationship between entrepreneurship, small business, and economic growth. The conceptual framework presents the links between franchising and economic growth at different levels of aggregation. In particular, it gives a summary of some research works across the world. The study being review - based study came out with the results which corroborate that franchises have got a significant impact on the development of a particular nation not only economically; also, socially and culturally. Even during the recession of 2007-2009, unlike all other businesses, franchised businesses weathered the downtown better. It has been found that if we lend $\$ 1$ million to franchised businesses will create or sustain an estimated $40 \%$ of jobs and will generates an estimated $\$ 4.2$ million in economic output (FRANdata,2009). An increase in capital flow to the franchising sector could have a significant positive impact on the economy of the country. These franchised small businesses offers innovative new products and services to consumers. It allows the entrepreneurs to open up new opportunities for growth by pursuing new markets overseas. Undoubtedly, the future of franchising looks bright, especially if the business environment provides a fertile ground for these firms to prosper and grow. Franchises flourish under the right business conditions like the right mix of tax and regulatory policies, a growing economy, and sufficient credit for both franchisees and franchisors. However, if these conditions are lacking in the economy, any of the small businesses will not be able to grow as rapidly, nor will the franchises. The study established the role played by the franchises in the economy by reviewing the work of various researchers and concluded that franchising remains a viable option for many 
entrepreneurs wishing to pursue the business expansion and growth dream despite the various economic challenges.

\section{REFERENCES}

Acs, Z.J. and D.B. Audretsch. 1993. "Small firms and entrepreneurship: An East-West perspective." Cambridge, UK: Cambridge University Press.

Acs, J. and A. Varga. 2005. Agglomeration, Entrepreneurship and Technological Change. Small Business Economics.

Acs, Z. J. and D.B.Audretsch. 2003. International handbook of entrepreneurship research. The Netherlands: Kluwer Academic Publishers.

Aldrich, H. and E.R Auster. 1986. Even dwarfs started small: Liabilities of age and size and their strategic implications. Research in Organizational Behavior 8 (2): 165-198.

Alon, I. and B. Moshe. 2000 .Executive insights: Franchising opportunities and threats in Russia. Journal of International Marketing 8 (3): 104-19.

Audretsch, B. David, and R. Thurik. 2001. Linking entrepreneurship to growth. Paris: OECD Directorate for Science. Technology and Industry Working Papers.

Barreto, H. 1989. The entrepreneur in microeconomic theory: Disappearance and explanation. London: Routledge.

Baucus, D.A., M.S. Baucus, and S.E. Human. 1996. Consensus in franchise organizations: A cooperative arrangement among entrepreneurs. Journal of Business Venturing 11 (5): 359-378.

Borowiecki R. and B. Siuta-Tokarska. 2008 Problems functioning and developing small and medium-sized enterprises in Poland. Synth Research directions actions, Difin, Warsaw.

Carlsson, B. 1992. The rise of small business; causes and consequences. In W. J. Adams (Ed.), Singular Europe, economy and policy of the European community after 1992: 145-169. Ann Arbor, MI: University of Michigan Press.

Carree, M. and A. R.Thurik. 1998. Small firms and economic growth in Europe. Atlantic Economic Journal 26 (2): 137-146.

Carree, M. and A. R. Thurik. 2002. "The Impact of Entrepreneurship on Economic Growth.” International Handbook of Entrepreneurship Research. The Netherlands: Kluwer Academic Publishers. 
Clarkin, J. E. and P. J. Rosa. 2005. Entrepreneurial teams within franchise systems. International Small Business Journal 23: 303 - 334.

Combs, J.G., D.J.Ketchen, C.L. Shook, and J.C. Short. 2010. Antecedents and consequences of franchising: Past accomplishments and future challenges. Journal of Management 37(1): 99-126.

Dant, R.P., S.K. Weaven., B.L. Baker, and H.J. Jeon.2011. An introspective examination of single unit versus multi-unit franchisees. Journal of the Academy of Marketing Science 41(1): $473-496$.

Dejardin, M. 2000. Entrepreneurship and economic growth: An obvious conjunction? Namur, Belgium: University of Namur.

Di Pietro, R., D. Severt., D. Welsh, and P. Raven. 2007. Franchisee leadership traits vs. manager leadership traits an exploratory study comparing hope, leadership, commitment and service quality delivery, Springer Science Business Media, LLC.

DiPietro, R.B., D.H.B. Welsh., P.V. Raven, and D. Severt. 2007. A measure of hope in franchise systems: Assessing franchisees, top executives, and franchisors. Journal of Leadership and Organizational Studies 13 (3): 59-66.

Dwivedy,R. 2002. Franchising indeed could become the business ambassador of world peace through global economic prosperity. Franchising World (17 April): 17.

Fadairo, M. and C. Lanchimba. 2017. "Franchising in Latin America - Handbook of Research on Franchising, Ed. F. Hoy, R. Perrigot, A. Terry. Edward Elgar.

Falbe, C. M., T. C Dandridge, and A. Kumar. 1998. The effect of organizational context on entrepreneurial strategies in franchising.Journal of Business Venturing 14: 125 - 140.

Falbe, C. M., T. C. Dandridge, and A. Kumar. 1999. The effect of organizational context on entrepreneurial strategies in franchising. Journal of Business Venturing 14 (1): 125-140.

FRANdata. 2009. Small business lending matrix and analysis: The impact of the credit crisis on the franchise sector. Washington, DC: International Franchise Association.http://www.franchise.org/uploadedFiles/Franchise Industry/Resources /Education_Foundation/SBLMandAnalysis201 0_Finalv3.pdf.

Gartner, W. 1985. A conceptual framework for describing the phenomenon of new venture creation. Academy of Management Review 10 (4): 696-706.

Gillis, W.E., E. McEwan, T. Russell Crook, and S.C. Michael. 2011. Using tournaments to reduce agency problems: The case of franchising. Entrepreneurship Theory and Practice $427-447$ 
Global Entrepreneurship Monitor (GEM). www.gemconsortium.org/category_list.asp for a list of available documents.

Global Entrepreneurship Monitor 2000. Executive report. Wellesley, MA/London: Babson College/London Business School.

Global Entrepreneurship Monitor. 2002. Executive report. Wellesley, MA/London: Babson College/London Business School.

Grewal, D., G.R. Iyer, R.G. Javalgi, and L. Radulovich. 2011. Franchise partnership and international expansion: A conceptual framework and research propositions. Entrepreneurship Theory and Practice 35: 533-557.

Grzelak, K. and M. Matejun. 2013. Franchising as a concept of entrepreneurship development in the SME sector, In M. Matejun and A. Walecka (Eds.), Modern entrepreneurship in business practice: selected Issues (pp. 47-61). Lodz: Lodz University of Technology Press.

Hoy, F. and S. Shane. 1998. Franchising as an entrepreneurial venture form. Journal of Business Venturing 13 (2): 91-94.

International Franchise Association. 2016. Convention, www.mbda.gov/calendar/international-franchise.franchise.com\#IFA 2016 convention.

Jääskeläinen, M. 2000. Entrepreneurship and Economic Growth. Helsinki: Institute of Strategy and International Business.

Kantis, H., M. Ishida, and M. Komori. 2002. Entrepreneurship in emerging economies: The creation and development of new firms in Latin America and East Asia. Washington, DC: Inter-American Development Bank.

Kaufmann, P. J. and R.P. Dant. 1996. Multi-unit franchising: Growth and management issues. Journal of Business Venturing 11: 359 - 378.

Kaufmann, P.J. and S. Eroglu, 1999. "Standardization and adaptation in business format franchising". Journal of Business Venturing 14: 69-85.

Ketchen, D.J., J.C. Short, and J.G. Combs. 2011. Is franchising entrepreneurship? Yes, no, and maybe so. Entrepreneurship: Theory and Practice 35(3): 583-593.

Low, M.B. and I.C. MacMillan. 1988. Entrepreneurship: Past research and future challenges. Journal of Management 14 (2): 139-161.

Michael, S. C. 2003. First mover advantage through franchising, Journal of Business Venturing 18: $61-80$. 
Michael, S. C. 2000. Investments to create bargaining power: The case of franchising. Strategic Management Journal 21: 497 - 514.

Nickell, S. J. 1996. Competition and corporate performance. Joumal of Political Economy 104 (4): 724-746.

Nickell, S. J., N. Daphne, and N. Dryden. 1997. What makes firms perform well? European Economic Review 41: 783-796.

Organisation for Economic Co-operation and Development (OECD) 1998. Fostering entrepreneurship. Paris: OECD.

Organisation for Economic Co-operation and Development (OECD) 2002. Benchmarking: Fostering firm creation and entrepreneurship. Paris: OECD Directorate for Science, Technology and Industry.

Peretto, P. F. 1999. Industrial development, technological change, and long-run growth. Journal of Development Economics 59: 389-417.

Porter, M. E. 1990. The competitive advantage of nations. New York: Free Press.

Reynolds, P. D., D.B. William, and L.B. Erkko Autio, Cox and Michael Hay. 2002. Global entrepreneurship monitor: 2002 executive report. Wellesley, MA/London: Babson College/London Business School.

Saraogi, A. 2009. Exploring franchisor/franchisee relationship: Building a predictive model of franchisee performance. VISION - The Journal of Business Perspective 13 (1): 31-58.

Saunders, D. J. 2002. Franchising opportunities: Unlocking Africa's potential. http://www.africa-ata.org/franchising.htm.

Schmitz, J. A. 1989. Imitation, entrepreneurship and long-run growth. Journal of Political Economy 97 (3): 721-739.

Schumpeter, J. A. 1934. The theory of economic development. Cambridge, MA: Harvard University Press.

Schumpeter, J. A. 1911 [1934]. The theory of economic development: An inquiry into profits, capital, credit, interest and the business cycle (translation). Cambridge, MA: Harvard University Press.

Schumpeter, J. A. 1942. Capitalism, socialism, and democracy (3rd ed). New York: Harper and Bros.,

Shane, S. and S. Venkataraman. 2000. The promise of entrepreneurship as a field of research. Academy of Management Review 25: 217-226. 
Shane, S. A. and M. D. Foo, 1999. New firm survival: Institutional explanations for new franchisor mortality. Management Science 45: 142 - 159.

Siggel, E., P. Maisonneuve, and E. Fortin. 2003. Role of franchising in African economic development. Paper presented at the $17^{\text {th }}$ annual conference of the International Society of Franchising, San Antonio, Texas, February.

Stanworth, J., S. Healeas, D. Purdy, A. Watson, and C. Stanworth. 2003. Entrepreneurial teams, intellectual capital acquisition and knowledge management: New perspectives on franchising as a small business growth strategy. Proceedings of the Society of Franchising, San Antonio, Texas.

Stevenson, H., M. Roberts, and H. Grousbeck. 1989. New business ventures and the entrepreneur (3rd edition). Irwin Publishing: Homewood, IL.

Thurik, R., and S. Wennekers. 2001. A note on entrepreneurship, small business and economic growth. Rotterdam: Erasmus Research Institute of Management Report Series.

Welsh, D. B., D. E. Desplaces, and A. E. Davis. 2011. A comparison of retail franchises, independent businesses, and purchased existing independent business startups: Lessons from the kauffman firm survey. Journal of Marketing Channels 18: 3- 18.

Wennekers, S. and R. Thurik. 1999. Linking entrepreneurship and economic growth. Small Business Economics 13: 27-55. 